\title{
Hazardous waste from dental radiology
}

Sir,

Dental offices that house and operate standard radiography equipment must process the $\mathrm{X}$-ray films using photochemical-fixer, developer, and equipment cleaner. Each of these chemical solutions is unique and requires special handling and disposal procedures. There are a number of hazardous dental wastes that, when disposed of improperly, could cause harm to the environment. Examples include chemical solutions, lead foil film backing, mercury, scrap dental amalgam, fluorescent tubes, and batteries. ${ }^{[1]}$

The fixer that Dental offices use to develop X-ray is a hazardous material that should not be simply rinsed down the drain. Spent fixer solution contains approximately $4000 \mathrm{mg}$ of silver/L. ${ }^{[2]}$ Silver recovery unit should be used to recapture the silver from the fixer, and once the container is full, a Certified Waste Carrier should be contacted for recycling or disposal. The silver recovery unit cartridge should not be placed in the garbage. The de-silvered fixer solution can be mixed with developer and water and disposed of down the sewer or septic system. A digital X-ray unit should be utilized to minimize the need for fixer solutions. Spent developer is permitted to be discharged into the sewer or septic systems provided it is diluted with water. It contains a toxic substance hydroquinone when unused, it must be kept separate from dental wastewaters or any access to the local sewage or fresh water. Many cleaners for X-ray developer systems contain chromium, a toxic substance so the supplier should be asked for a cleaner that does not use chromium.

Undeveloped film contains a high level of silver and must be treated as a hazardous waste. ${ }^{[3]}$ Silver can contaminate the soil and groundwater if it is sent to a landfill. Unused film should be recycled rather than being placed into the waste. Any unused film that is going to be disposed of should be collected and placed in a container recommended by the disposal company (plastic alginate container is sufficient). Once the container is full, a certified waste carrier should be contacted for recycling or disposal. Digital X-ray unit should be used to minimize purchase of new X-ray films. Developed film has little residual silver and can be placed in the regular solid waste stream.
The lead foil inside each $\mathrm{X}$-ray packet is a leachable toxin and can contaminate the soil and groundwater in landfill sites..$^{[4]}$ The management can be done by collecting lead foil packets in a marked container, and once the container is full, a certified waste carrier should be contacted for recycling. Lead foil packets and lead aprons should not be thrown into the regular garbage. One should contact a certified waste carrier to recycle or dispose of unwanted lead aprons. In this way, a proactive approach will allow our profession to succeed in an era of increased public environmental concern and environmentally protective legislation.

\section{Ujwala Brahmankar}

Department of Oral Medicine and Radiology, ACPM Dental College, Dhule, Maharashtra, India

Address for the correspondence: Dr. Ujwala Brahmankar, Department of Oral Medicine and Radiology, ACPM Dental College, Dhule, Maharashtra - 424 003, India. E-mail: drujwala.brahmankar@gmail.com

\section{REFERENCES}

1. Sharma M. Hospital Waste Management and Its Monitoring. $1^{\text {st }}$ ed. New Delhi: Jaypee Brothers Medical Publication; 2002.

2. Anderson K. Creating an environmentally friendly dental practice. CDS Rev 1999;12-8.

3. Hedge V, Kulkarni RD, Ajantha GS. Biomedical waste management. J Oral Maxillofac Pathol 2007;11:5-9.

4. Swanson RL, Roethel FJ, Bauer H. Reuse of lead from dental X-rays. N Y State Dent J 1999;65:34-6.

\begin{tabular}{|c|c|}
\hline \multicolumn{2}{|l|}{ Access this article online } \\
\hline Quick Response Code: & \multirow{2}{*}{$\begin{array}{l}\text { Website: } \\
\text { www.ijmedph.org }\end{array}$} \\
\hline & \\
\hline & $\begin{array}{l}\text { DOI: } \\
\text { 10.4103/2230-8598.151278 }\end{array}$ \\
\hline
\end{tabular}

